\title{
PERBEDAAN PROSES PEMBELAJARAN DAN PRESTASI BELAJAR SISWA SD EKS-RSBI DAN SDSN DI DIY
}

\section{A COMPARATIVE OF THE LEARNING PROCESS AND ACHIEVEMENT GRADE STUDENTS OF EX-RSBI ELEMENTARY SCHOOLS AND NATIONAL STANDARD ELEMENTARY SCHOOLS IN DIY}

\author{
Herjan Haryadi, Heri Retnawati \\ IAIN Mataram Nusa Tenggara Barat, Universitas Negeri Yogyakarta \\ haryadi_herjan@yahoo.co.id, retnawati_heriuny@yahoo.co.id
}

\begin{abstract}
Abstrak
Penelitian ini bertujuan untuk mengetahui perbedaan proses pembelajaran dan prestasi belajar siswa eks-RSBI dan SDSN di DIY pada mata pelajaran matematika, IPA dan Bahasa Indonesia. Penelitian ini merupakan studi penelitian komparasi. Populasi dalam penelitian ini adalah seluruh siswa kelas IV dan V SD eks-RSBI dan SDSN di DIY. Analisis data menggunakan (1) statistik deskriptif untuk mendeskripsikan proses penelitian dan menggambarkan mean dari data yang diperoleh; dan (2) statistik inferensial menggunakan uji multivariat (Manova) dan uji univariat dengan uji $t$ untuk menguji hipotesis penelitian dengan taraf signifikansi 5\%. Hasil penelitian menunjukkan bahwa. (1) tidak terdapat perbedaan proses pembelajaran dan prestasi belajar matematika antara siswa SDSN dan SD Eks-RSBI di DIY, (2) terdapat perbedaan proses pembelajaran dan prestasi belajar IPA antara siswa SDSN dan SD Eks-RSBI di DIY, (3) terdapat perbedaan proses pembelajaran dan prestasi belajar Bahasa Indonesia antara siswa SDSN dan SD Eks-RSBI di DIY.
\end{abstract}

Kata Kunci: proses pembelajaran, prestasi belajar

\begin{abstract}
This study intends to know the differences in the learning process and learning achievement of the fourth and the fifth grade studentsofex-RSBI elementary schools (SD) and national standard elementary schools (SDSN) in Yogyakarta Special Territory (DIY)in learning mathematics, science, and Indonesian. This study is a comparative study. The population of this study is the fourth and the fifth grade students of the ex RSBI SD and SDSN in DIY. The data were analyzed using (1) descriptive statistics, to describe the process of the research and to describe the mean, median, and standard deviation of the collected data; and (2) inferential statistics by using the multivariate test (Manova) and univariate test using t-test to test the hypothesis with the significance level of 5\%. The result shows that. (1) there is no difference in the learning process and achievement in mathematics among the students of SDSN and those of ex-RSBI SD in DIY, (2) there is a difference in the learning process and achievement in science among the students ofSDSN and those of ex-RSBI SD in DIY,(3) there is a difference in the learning process and achievement in Indonesian among the students of SDSN and those of ex-RSBI SD in DIY.
\end{abstract}

Keywords: learning process, learning achievement 


\section{Pendahuluan}

Tuntutan era globalisasi dan teknologi saat ini terus berkembang dan tumbuh pesat sejalan dengan kebutuhan manusia yang semakin meningkat, dengan semakin meningkatnya kebutuhan manusia, secara tidak langsung akan menuntut segala aspek yang berpengaruh di dalamnya terutama dalam bidang pendidikan, itu sendiri. Oleh karena itu pemerintah terus berusaha untuk meningkatkan mutu dan kualitas pendidikan di Indonesia sampai saat sekarang ini. Sebagaimana tertuang dalam pembukaan UUD 1945 yang menyatakan bahwa salah satu tujuan negara Republik Indonesia adalah mencerdaskan kehidupan bangsa dan untuk itu setiap warga negara Indonesia berhak memperoleh pendidikan yang bermutu dan lebih baik.

Peningkatan mutu pendidikan sebagai bagian yang tidak terpisahkan dari proses pengembangan sumber daya manusia, harus dilakukan secara terencana, terarah, dan intensif sehingga mampu menyiapkan bangsa Indonesia memasuki era globalisasi yang sarat dengan persaingan (Depdiknas, 2006, p.3). Berbicara tentang mutu dan kualitas pendidikan, pemerintah telah merencanakan peningkatan mutu pendidikan sebagaimana dijelaskan dalam pasal 50 ayat 3 UU No 20 tahun 2003 tentang pengadaan peningkatan pendidikan dari Sekolah Standar Nasional (SSN) menjadi Rintisan Sekolah Berstandar Internasional (RSBI).

Sekolah Dasar (SD) eks RSBI merupakan salah satu wujud upaya peningkatan mutu pendidikan pada sekolah dasar berstandar nasional, yang keberadaanya sesuai amanat Undang-Undang No.20 tahun 2003 tentang sistem pendidikan nasional.

SDSN merupakan salah satu wujud peningkatan lembaga pendidikan dasar. SDSN diharapkan dapat menjamin mutu pendidikan sekolah dasar dalam rangka mencerdaskan kehidupan bangsa dan membentuk watak serta peradaban bangsa yang bermartabat untuk mendukung cita-cita membangun manusia seutuhnya yaitu "insan Indonesia cerdas dan kompetitif meliputi cerdas spiritual, cerdas emosional, cerdas social, cerdas intlektual dan cerdas kinestetis. Kompetitif mengandung makna berkperibadian unggul, bersemangat juang tinggi, mandiri, pantang menyerah, inovatif dan produktif (Depdiknas, 2007, p.i).

Beberapa pemaparan tersebut sebenarnya sudah memberikan jawaban dan tujuan yang maksimal terhadap apa yang diharapkan pemerintah ke depannya terutama dalam hal karakter dan kecerdasan spritual peserta didik sehingga ke depan akan lebih dapat meningkatkan mutu pendidikan menjadi lebih baik, salah satu caranya tentu adalah dengan mengelola proses pembelajara dan meningkatkan prestasi belajar siswa, sebagaimana tertuang dalam standar proses pendidikan yaitu "proses pembelajaran pada setiap satuan pendidikan dasar dan menengah harus interaktif, inspiratif, menyenangkan, menantang, dan memotivasi peserta didik untuk berpartisifasi aktif, serta memberikan ruang yang cukup bagi prakarsa, kreativitas, dan kemandirian sesuai dengan bakat, minat, dan perkembangan fisik serta psikologis peserta didik (Kemendiknas, 2007, p.6).

Prestasi belajar merupakan bagian yang terpenting yang tidak bisa terpisahkan dari proses pembelajaran, baik dan buruknya prestasi belajar siswa tentu akan sangat berpengaruh pada terlaksananya proses pembelajaran. Mardapi (2012, p.2) tujuan sekolah sebagai lembaga pendidikan adalah mengembangkan potensi peserta didik secara optimal menjadi kemampuan untuk hidup dimasyarakat. Pengembangan potensi peserta didik dilakukan melalui proses pembelajaran.

Proses pembelajaran merupakan sesuatu keadaan yang dimulai dengan perencanaan, pelaksanaan dan evaluasi yang terjadi dalam segala aktivitas belajar siswa. Mardapi (2012, p.4) upaya meningkatkan kualitas pendidikan dapat ditempuh melalui peningkatan kualitas pembelajaran dan kualitas sistem penilaiannya. Dalam dunia pendidikan, belajar bukan hanya mengukur kognitif siswa, akan tetapi ranah afektif dan psikomotorik siswa perlu dinilai selama proses pembelajaran berlangsung.

Pendidikan yang baik adalah yang mampu menghasilkan output atau berprestasi dan berkualitas serta memiliki kemampuan yang bisa bermanfaat bagi orang lain. Kemampuan tersebut tidak akan terlepas terhadap terlaksananya proses pembelajaran yang berlangsung di sekolah.

Prestasi belajar mempunyai peranan penting dalam proses pembelajaran. Proses penilaian terhadap prestasi belajar dapat memberikan informasi kepada guru tentang kemajuan dan ketidak pahaman siswa dalam upaya mencapai tujuan-tujuan belajarnya melalui kegiatan belajar serta untuk mengevaluasi pemahaman siswa. 
Berdasarkan beberapa penjelasan di atas bahwa pada hakekatnya syarat yang telah ditentukan oleh pemerintah kepada SD eks RSBI sudah sangat jelas, akan tetapi dari hasil survei yang telah dilakukan kenyataannya tidak seperti apa yang diharapkan oleh pemerintah kepada sekolah SD Eks RSBI, diantaranya yaitu bahwa kurikulum yang digunakan SD eks RSBI masih menggunakan kurikulum standar nasional, SDM masih sama dengan SDSN, proses pembelajaran di SDSN dan SD eks RSBI terlihat masih sama (hasil pengamatan di SD Eks RSBI 1 Bantul).

Berdasarkan laporan Dinas Pemuda dan Olahraga (Dinas Pendidikan Pemuda dan Olahraga Daerah Istimewa Yogyakarta, 2012) bahwa terdapat siswa yang meraih nilai UN tertinggi pada tahun 2013 berinisial AD dari Sekolah Dasar Negeri Nogopuro dengan meraih nilai Matematika 10,00, nilai IPA 10,00 dan nilai bahasa indonesia 9,8 .

Dengan hal-hal yang terjadi disekitar dunia pendidikan yang mengarahkan kepada prestasi belajar siswa sehingga berbagai sorotan publik terus bermunculan, muncullah pemikiran untuk melihat lebih luas terlaksananya dan tercapainya prestasi belajar siswa berdasarkan kategori-kategori yang telah ditetapkan oleh pemerintah.

Belajar

Menurut David Ausubel (Prasetyo, 2004, p.3) mengklasifikasikan belajar kedalam 2 dimensi. Pertama, dimensi penerimaan/penemuan, berhubungan dengan cara bagaimana suatu materi pelajaran disampaikan atau dipresentasikan. Belajar penerimaan dimaksudkan siswa menerima informasi atau materi pelajaran dalam bentuk sudah "fixed" atau final. Sedangkan belajar penemuan, siswa diharapkan dapat menemukan sendiri informasi atau konsep dari materi pelajaran yang disampaikan. Dimensi kedua yaitu belajar bermakna/hafalan, berhubungan dengan bagaimana siswa mengkaitkan materi pelajaran baru dengan struktur kognitif yang telah ada pada diri siswa. Bruner (Prasetyo, 2004, p.6) menambahkan bahwa memandang manusia sebagai pemroses, pemikir, dan pencipta informasi. Berangkat dari cara pandang tersebut, Bruner memusatkan perhatiannya pada apa yang dilakukan manusia terhadap informasi yang di terima dan apa yang dilakukan setelah menerima informasi tersebut untuk mencapai pemahaman. Sehingga inti dari belajar tersebut adalah cara-cara bagaimana manusia memilih, mempertahankan, dan mentransformasikan informasi secara aktif. Menurut American Heritage (Hergenhanh \& Olson, 2010, p.2) menyatakan "to gain knowledge, comprehension, or mastery throuh experience or study". Maksudnya belajar adalah untuk mendapat pengetahuan, pemahaman, dan penguasaan melalui pengalaman atau studi.

Brown dan Knight (Bundu, 2006, p.14) memberikan definisi lebih dalam tentang intisari belajar pada hakekatnya adalah sebagai berikut: "changes in knowledge, understanding, skills, and attitudes brought about by experience and reflection upon that experience" dengan kata lain inti belajar adalah adanya perubahan pengetahuan, pemahaman, keterampilan, dan sikap yang diperoleh melalui pengalaman dan refleksi pengelaman.

\section{Proses Pembelajaran}

Rusman (2012, p.106) menyatakan bahwa pelaksanaan/proses pembelajaran adalah suatu bentuk penyelenggaraan kegiatan pembelajaran yang memadukan secara sistematis dan berkesinambungan kegiatan pembelajaran yang dilakukan di dalam kelas dengan kegiatan pembelajaran yang dilakukan di luar kelas. Lanjut Rusman (2012, p.108) Mengamati pelaksanaan pembelajaran lebih menekankan pada proses pembelajaran, hasil, efektifitas, dan keberhasilan guru dalam merencanakan dan melaksanakan kegiatan pembelajaran.

Guru adalah kunci dari keberhasilan siswa. Christa McAuliffe (Santrock, 2010, p.4) mengatakan bahwa sebagai seorang guru, anda akan menyentuh masa depan karena anak-anak adalah masa depan dalam masyarakat mana pun. Rusman (2012, p.105) mengungkapkan bahwa lulusan yang diperlukan tidak sekedar yang mampu mengingat dan memahami informasi, tetapi mampu menerapkannya secara kontekstual melalui beragam kompetensi artinya adalah output dari hasil proses pembelajaran tersebut yaitu mampu mengaflikasikan semua teori yang telah dipelajari dalam kehidupan sehari-hari dan bermanfaat bagi orang lain.

Sanjaya (2006, p.58) menjelaskan bahwa sebagai suatu sistem, suatu proses pembelajaran terdiri dari beberapa kriteria atau komponen, dimana satu sama lain saling berinteraksi dan berinterelasi. Komponen-komponen tersebut adalah tujuan, materi pelajaran, metode, atau strategi pembelajaran, media, dan evaluasi. Sebagaimana akan digambarkan pada bagan di bawah ini 


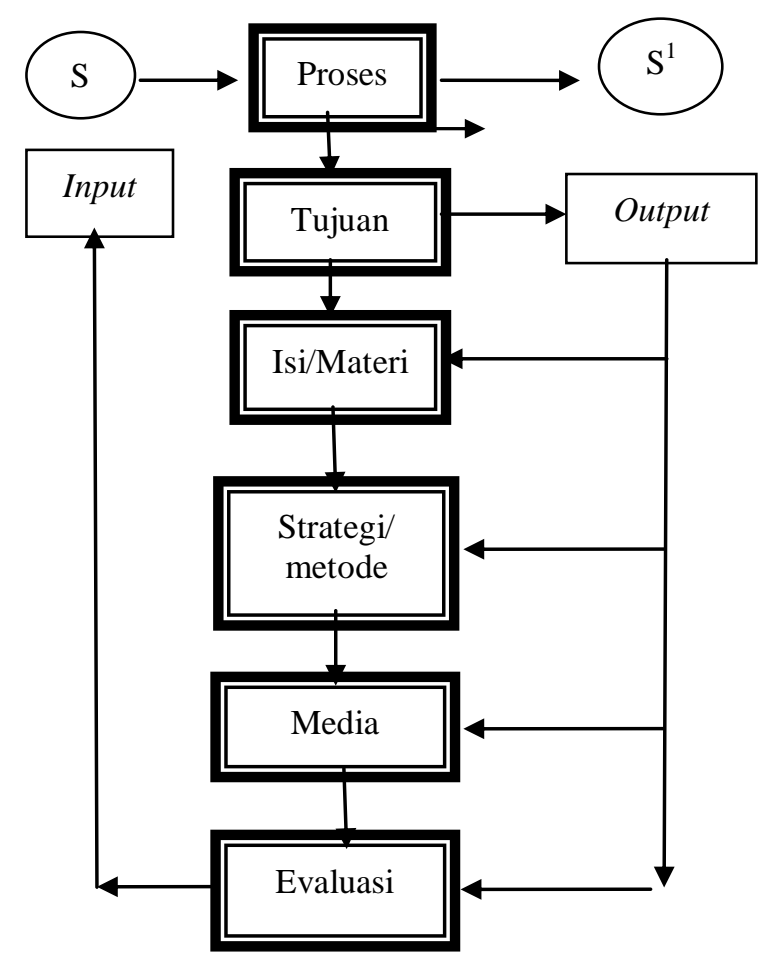

Gambar 1. Bagan Komponen Proses Pembelajaran

Komponen-komponen dari kriteria proses pembelajaran tersebut dapat diuraikan sebagai berikut: (a) tujuan merupakan bagian komponen proses pembelajaran yang sangat penting dalam sistem pembelajaran. Sanjaya menjelaskan (2006, p.59) sesuai dengan standar kompetensi, kurikulum yang berlaku untuk setiap satuan pendidikan adalah kurikulum berbasis kompetensi, (b) Sanjaya (2006, p.60) materi pelajaran merupakan inti dalam proses pembelajaran. oleh sebab itu dapat dikatakan bahwa tujuan utama pembelajaran adalah pemahaman, dan penguasaan materi pelajaran (subject centered teaching). Karena itu guru perlu dan mutlak memahami secara detail isi materi pelajaran yang akan disampaikan dan yang akan dikuasai siswa, (c) Strategi pembelajaran adalah suatu perangkat materi dan prosedur pembelajaran yang digunakan secara bersama-sama untuk menimbulkan hasil belajar pada peserta didik atau siswa, (d) Gerlach and Ely (1980, p.244) menyatakan "A medium, conceived is any person, material or event that establishs condition which enable the learner to ecquire knowledge, skill, and attitude." maksudnya adalah bahwa secara umum media itu meliputi orang, bahan, peralatan atau kegiatan yang menciptakan kondisi yang memungkinkan siswa memperoleh pengetahuan, keterampilan dan sikap. (e) Evaluasi merupakan komponen terakhir dalam proses pembelajaran, merupakan penentu ketercapaian dan sebagai ukuran dari keberhasilan atau kegagalan proses pembelajaran tersebut.

Prestasi Belajar

Menurut Jhonson \& Jhonson, (2002, p.8) berpendapat tentang prestasi belajar sebagai berikut

(a) achivement related behavior (ability to communicated, cooperative, perform certain activities and solve complex problem), (b) achivement related products (writing rhemes or product report, art product, craft product) or (c) achivement related attitude and dispositions (proide in the work, desire to improve contually one's competencies, commitment to quality, internal locus of control, self esteem).

Berdasarkan definisi tersebut dapat disimpulkan bahwa definisi prestasi telah berkembang menurut hubungannya yaitu (a) prestasi yang berhubungan dengan tingkah laku, (b) prestasi yang berhubungan dengan hasil (c) prestasi yang berhubungan dengan sikap dan waktu.

Ketercapaian prestasi belajar yang lebih baik memerlukan tujuan dan sasaran pengajaran yang harus dispesifikasikan dan dipahami dengan sebaik-baiknya, bukan hanya sekedar mengajarkan ilmu pengetahuan tanpa memahami indikator dari prestasi belajar tersebut. Prestasi tentu akan sangat menentukan karakteristik siswa untuk menempatkan dirinya dalam kehidupan, memilih dan mengimbangi hidup dalam pergaulannya dengan sesama.

Menurut Oliva (1992, p.382) menjelaskan bahwa:

The instructional goals and objective should be spesified for three domains of leaning-the cognitife, the affective and the psychomotoric, whenever applicable. Note these three illustrations of different types of learning: (1) knowledge of the system of election primaries, (2) enjoyment in reading, (3) skill in laying bricks

artinya bahwa sasaran dan tujuan harus dispesifikasi dalam tiga ranah pembelajaran yaitu kognitif, afektif dan psikomotorik, kapanpun dapat diaplikasikan. Contoh dalam tiga ranah ini yaitu pengetahuan dari sistem pemilihan, 
kesenangan membaca, dan keterampilan dalam menempatkan batasan.

Indikator prestasi belajar berdasarkan teori Bloom dijelaskan oleh Oliva (1992, p.383) yaitu

cognitive domain. Benjamin S. Bloom defined the cognitife domain as including objectives that" deal with the racall or recognition of knowledge and the development of intellectual abilities and skills. " cognitive learning, which involve the mental, processing, range from memorization to the ability to think and solve problem

Bloom menjelaskan bahwa bidang kognitif termasuk tujuan yang berhubungan dengan mengingat atau mengenali pengetahuan dan pengembangan dari kemampuan dan keterampilan intlektual. Pembelajaran kognitif yang termasuk kemajuan mental, mencakup dari mengingat sampai pada kemampuan untuk berpikir dan memecahkan masalah.

affective Domain. David R. Krathwohl, Benjamin S. Bloom, and Bertram B. Masia defined the affective domain as including objectives that "emphasize a felling tone, as emotion, or a degree of acceptance or rejection." affective learnings encompass the emotions, fellings, beliefs, attitudes, and values

Artinya bahwa bidang afektif termasuk tujuan dalam menegaskan nada perasaan, emosi, atau tingkat penerimaan dan penolakan. Pembelajaran afektif meliputi emosi, perasaan, sikap dan nilai. Menurut Krathwohl, dkk (1973, p.95) menggambarkan bagian-bagian/ranah dari domain afektif itu sendiri yaitu (1) receiving (attending), (a) awareness, (b) willingness to receive, (c) controlled or selected attention; (2) Responding, (a) acquescence in responding, $(b)$ willingness to respond, (c) satisfaction in response; (2) valuing, (a) Acceptance of a value, (b) preference for a value, (c) Commiment (conviction); (3) Organization, (a) conceptualization of a value, (b) organization of a value system, (c) characterization by a value or value complex, (d) generalized set, (e) characterization

Berdasarkan tingkatan ranah afektif menurut Krathwohl ada lima, yaitu: (1) Menerima (receiving) Maksudnya adalah adanya kesadaran ingin menerima dan sadar akan adanya sesuatu rangsangan dari lingkungan sekitarnya sehingga individu berusaha terbuka,
(2). Pemberian respon (responding) Artinya adanya timbal balik atau respon siswa untuk melakukan tindakan sebagai respon pada perangsang tersebut. (3). Penilaian (valuing) maksudnya adanya keyakinan siswa terhadap respon yang telah dirasakan secara nikmat dan puas sehingga menyebabkan individu ingin secara konsisten menampilkan tindakan itu dalam situasi yang serupa. (4). Organisasi (organization) artinya peserta didik sudah mulai mampu mengorganisasikan dan memilah beberapa nilai yang dominan bagi dirinya dari respon atau penerimaan yang dihasilkan tersebut sehingga peserta didik akan dapat menempatkan sistem nilai tersebut menjadi lebih baik. (5). Karakterisasi/pembentukan pola hidup (Characterization by a value or value complex) Tingkatan Ini adalah tingkatan tertinggi dari aspek afektif yang lebih mengacu kepada karakter dan daya hidup seseorang, dari penerimaan sampai pengorganisasian, individu akan terlihat pada tahapan ini yaitu di mana individu akan berlaku konsisten berdasarkan nilai yang dijunjungnya.

Psychomotor Domain

Menurut Harrow (1971, p.32) mengklarifikasikan beberapa bagian dari domain psikomotorik yaitu (1) Reflex Movements, (2) Basic Fundamental Movements, (3)Perceptual Abilities, (4) Physical Abilitiies, (5) Skilled Movements, (6) Non Discursive Communications

Maksud dari penjelasan tersebut adalah sebagai berikut: (1) Peniruan adalah Adanya respon serupa dengan yang diamati. (2) Manipulasi artinya Lebih menekankan terhadap kemampuan mengikuti penampilan, arahan yang menetapkan suatu penampilan melalui latihan. (3) Ketetapan/ kemampuan persepsi maksudnya adalah memerlukan kecermatan, proporsi dan kepastian yang lebih tinggi dalam penampilan. (4) Artikulasi artinya Lebih menekankan pada koordinasi rangkaian gerakan dengan membuat urutan yang tepat dan mencapai yang diharapkan. (5) Keterampilan atau pengalamiahan adalah adanya keterampilan secara alamiah dari akibat peniruan yang telah dilakukan oleh siswa atau gerakannya dilakukan secara rutin.

Menurut Brown (1981, p.2) by achievement we mean the knowledge, understending, and skills acquired as a result of specified educational experiences. Maksudnya adalah dengan prestasi seseorang dapat merata-ratakan pengetahuan, memahami dan memperoleh ke- 
mampuan-kemampuan seperti hasil dari pengalaman pendidikan secara spesifik yang lebih menekankan pada pengetahuan dan skill (kemampuan).

Untuk mengukur prestasi belajar siswa, tes hasil belajar merupakan alat yang tidak bisa terpisahkan dalam mengukur kemampuan dan pemahaman siswa setelah mempelajari berbagai materi yang diajarkan. Tes hasil belajar yang akan diberikan ke siswa terdiri dari beberapa soal yang telah tersusun berdasarkan standar kompetensi dan kompetensi dasar dari materi yang diajarkan selama proses pembelajaran. Menurut Reynold, dkk (2009, p.300) menegaskan bahwa "achievement test are designed to assess students' knowledge or skill in a content domain in which they have received instruction". Tes prestasi dirancang untuk menilai pengetahuan siswa atau keterampilan dalam konten domain dimana mereka telah menerima pembelajaran.

\section{Metode Penelitian}

Jenis dan Desain Penelitian

Penelitian ini menggunakan pendekatan kuantitatif deskriptif dengan jenis penelitian komparatif, yaitu pada perbedaan proses pembelajaran dan prestasi belajar siswa di SD Eks RSBI dan SDSN kelas IV dan V. McMillan (2010, p.222), penelitian komparatif adalah meneliti hubungan dari satu variabel dengan variabel yang lain untuk menguji apakah nilai dari variabel bebas dalam satu grup berbeda dari nilai variabel terikat pada kelompok yang lain.

Tempat dan Waktu Penelitian

Penelitian ini dilaksanakan di SD eks RSBI dan SDSN se-DIY dengan kategori delapan SDSN yaitu tiga sekolah di Kabupaten Gunungkidul, tiga sekolah di Kabupaten Bantul, dua sekolah di Kabupaten Kulonprogo dan tiga SD Eks RSBI, masing-masing satu sekolah di Kabupaten Kulonprogo, Kabupaten Gunungkidul dan Kabupaten Bantul. Waktu penelitian dilaksanakan pada bulan Agustus 2012-Mei 2013.

\section{Populasi dan Sampel Penelitian}

Populasi dalam penelitian ini adalah semua siswa SDSN dan SD eks RSBI di wilayah DIY. Sedangkan Sampelnya adalah 605 orang siswa kelas IV dan V SDSN dan 342 siswa kelas IV dan V SD eks RSBI. teknik yang digunakan dalam pengambilan sampel adalah dengan teknik proportional sampling dan hasilnya sebagai berikut:

Tabel 1 Daftar Sampel Penelitian SDSN DIY

\begin{tabular}{cccc}
\hline No & $\begin{array}{c}\text { Kabupaten/ } \\
\text { Kota }\end{array}$ & Nama sekolah & $\begin{array}{c}\text { Jumlah } \\
\text { sampel }\end{array}$ \\
\hline 1 & Bantul & $\begin{array}{c}\text { SDN 3 Bantul } \\
\text { SDN Jejeran. } \\
\text { SDN Jetis }\end{array}$ & 317 \\
& & SDN Paliyan II & 172 \\
3 & Kulonprogo & $\begin{array}{c}\text { SDN Semanu III } \\
\text { SDN } \\
\text { Bendungan IV } \\
\text { SDN Jlaban } \\
\end{array}$ & $\begin{array}{c}\text { SDN Percobaan } \\
\text { IV }\end{array}$ \\
& & 116 \\
& & $\mathbf{6 0 5}$ \\
\hline
\end{tabular}

Tabel 2. Daftar Sampel Penelitian SD Eks RSBI DIY

\begin{tabular}{ccccc}
\hline No & $\begin{array}{c}\text { Kabupaten/ } \\
\text { Kota }\end{array}$ & $\begin{array}{c}\text { Nama } \\
\text { sekolah }\end{array}$ & $\begin{array}{c}\text { Jumlah } \\
\text { sampel }\end{array}$ & Proporsi \\
\hline 1 & Bantul & $\begin{array}{c}\text { SDN } \\
\text { Bantul } \\
\text { Manunggal } \\
\text { SDN 1 }\end{array}$ & 97 & 97 \\
2 & Gunungkidul & 123 & 123 \\
Wonosari & SDN 4 & 122 & 122 \\
& Kulonprogo & $\begin{array}{c}\text { Wates } \\
\text { Jumlah }\end{array}$ & 342 & 342 \\
\hline
\end{tabular}

Variabel Penelitian

Menurut Sukmadinata (2007, p.195) Variabel bebas merupakan variabel yang memberikan pengaruh atau sering disebut variabel perlakuan, sedangkan variabel terikat adalah variabel yang diukur sebagai akibat dari variabel yang memberikan pengaruh. Variabel bebas dari penelitian ini adalah SD eks RSBI dan SD SSN sedangkan variabel terikatnya adalah proses pembelajaran dan prestasi belajar.

Teknik dan Instrumen Penelitian

Tehnik pengumpulan data pada penelitian ini menggunakan: (a) teknik tes,bertujuan untuk mengetahui dan mengukur kemampuan kognitif siswa, (b). Teknik angket, bertujuan untuk mengetahui dan mengukur sikap atau proses belajar siswa, (c). Teknik observasi. Tujuannya adalah mengetahui sikap, keterampilan dan berjalannya proses pembelajaran di dalam kelas. Sedangkan Instrumen penelitian dalam pengumpulan data yang digunakan dalam penelitian ini adalah sebagai berikut (a) tes prestasi belajar siswa. (b) angket dan (c). observasi. 
Validitas dan Reliabilitas Instrumen Penelitian

Azwar (2012, p.8) validitas adalah sejauhmana akurasi suatu tes atau skala dalam menjalankan fungsi pengukurannya.

Analisis yang digunakan untuk menguji validitas adalah exploraitory factor analysis (EFA) dengan bantuan software SPSS 16 for windows. Hasil analisis EFA sebagai uji persyaratan analisis diperoleh dari nilai Kaiser Meyer-Olkin Measure of sampling Adequacy sebesar 0,528 dengan nilai Bartlett's tes of Sphericity sebesar 797.916 pada derajat keabsahan 435 dengan taraf signifikansi 0,000 sehingga dapat dikatakan baik, pada angket proses pembelajaran Matematika, pada angket proses pembelajaran IPA sebesar 0,543 dengan nilai Bartlett's tes of Sphericity sebesar 884.096 pada derajat keabsahan 435 dengan taraf signifikansi 0,000 sehingga dapat dikatakan baik dan pada angket Bahasa Indonesia sebesar 0,520 dengan nilai Bartlett's tes of Sphericity sebesar 1.034E3 pada derajat keabsahan 435 dengan taraf signifikansi 0,000 sehingga dapat dikatakan baik.

Sedangkan reliabilitas instrumennya menggunakan koofesien Alpha Cronbach sebagai berikut:

$\alpha=\frac{k}{k-1}\left(1-\frac{\sum S_{i}^{2}}{S^{2}}\right)$ (Usman, dkk (1995,

p.291)

Hasil uji reliabel dari instrumen yang digunakan pada penelitian ini adalah reliabel yaitu dengan nilai $>0,070$, berdasarkan standar nilai Alpha Cronbach.

Teknis Analisis Data

Analisis data menggunakan analisis data statistik deskriptif dan analisis data statistik inferensial yaitu dengan menggunakan uji multivariat atau MANOVA (To Group Multivariate Analysis of Variance) dan apabila terdapat perbedaan setelah itu dilakukan uji Univariat dengan menggunakan $\mathrm{t}$ tes one sampel . rumus dari MANOVA sebagai berikut:

$\mathrm{T}^{2}=\frac{n_{1} n_{2}}{n_{1}+n_{2}}\left(\overline{\mathrm{y}}_{1}-\overline{\mathrm{y}}_{2}\right)^{\prime} s^{-1}\left(\overline{\mathrm{y}}_{1}-\overline{\mathrm{y}}_{2}\right)$ (Stevens, 2002, p.176)

\section{Hasil Penelitian}

Hasil analisis dan pengujian data secara kuantitatif deskriptif dan analisis data secara inferensisal memberikan gambaran secara em- piris pada penelitian ini, baik secara kuantitatif dan kualitatif.

Berdasarkan hasil perhitungan analisis dan pengujian data di atas telah memperlihatkan bahwa secara keseluruhan dari satu provinsi DIY, terdapat tiga hasil penelitian dalam penelitian tersebut yaitu pertama, tidak terdapat perbedaan yang signifikan antara proses pembelajaran dan prestasi belajar Matematika siswa SDSN dengan siswa sekolah SD Eks RSBI. Hal ini terlihat dari jumlah rata-rata (mean) skor prestasi belajar Matematika di SD Eks RSBI yang lebih tinggi, namun tidak jauh terpaut dengan purata skor proses pembelajaran dan prestasi belajar matematika siswa sekolah di SDSN. rata-rata (mean) prestasi belajar matematika SD Eks RSBI adalah sebesar 53,23 sedangkan purata skor prestasi belajar Matematika SDSN adalah 51,91 dengan selisih yang hanya 1,32 dan rata-rata (mean) proses pembelajaran matematika siswa SD Eks RSBI sebesar 81,63, sedangkan SDSN sebesar 81,76 dengan selisih 0,13 lebih tinggi di bandingkan SD Eks RSBI. Akan tetapi melalui hasil perhitungan uji Manova juga menggambarkan nilai signifikansi diperoleh bilangan $\mathrm{p}$-value $=$ 2,525 lebih besar dari $\alpha=0,05$ maka $\mathrm{H}_{0}: \mu_{1} \geq$ $\mu_{2}$ tidak dapat ditolak.

Kedua, terdapat perbedaan yang signifikan antara proses pembelajaran dan prestasi belajar IPA siswa sekolah SDSN dengan siswa sekolah SD Eks RSBI. Hal ini terlihat dari jumlah rata-rata (mean) skor prestasi belajar IPA siswa sekolah SDSN yang lebih tinggi namun tidak jauh terpaut dengan purata skor prestasi belajar IPA sekolah SD Eks RSBI. ratarata (mean) SD Eks RSBI adalah sebesar 73,03 sedangkan rata-rata skor prestasi belajar IPA siswa sekolah SDSN adalah 74,93. Dengan selisih 1,90 dan rata-rata (mean) proses pembelajaran IPA SD Eks RSBI adalah sebesar 82,58 sedangkan rata-rata skor proses pembelajaran IPA siswa sekolah SDSN adalah 83,83 lebih tinggi dari skor rata-rata SD Eks RSBI dengan selisih 1,25. Akan tetapi dengan mengacu pada hasil perhitungan uji Manova signifikansi diperoleh bilangan $\mathrm{p}$-value $=0,002$ lebih kecil dari $\alpha=0,05$ maka $\mathrm{H}_{0}: \mu_{1} \leq \mu_{2}$ ditolak.

Ketiga, terdapat perbedaan yang signifikan antara proses pembelajaran dan prestasi belajar Bahasa Indonesia siswa sSDSN dengan SD Eks RSBI. Dimana rata-rata (mean) skor prestasi belajar Bahasa Indonesia siswa SD Eks RSBI yang lebih tinggi namun tidak jauh terpaut dengan rata-rata skor prestasi belajar 
Bahasa Indonesia siswa sekolah SDSN. ratarata (mean) SD Eks RSBI adalah sebesar 58,40 sedangkan rata-rata skor prestasi belajar Bahasa Indonesia siswa sekolah SDSN adalah 54,79 dengan selisih 3,61 dan rata-rata (mean) proses pembelajaran Bahasa Indonesia SD Eks RSBI adalah sebesar 83,46 sedangkan rata-rata skor proses pembelajaran Bahasa Indonesia siswa sekolah SDSN adalah 82,47 lebih rendah dari skor rata-rata SD Eks RSBI dengan selisih 0,99, dengan mengacu pada hasil perhitungan uji Manova signifikansi diperoleh bilangan $\mathrm{p}$-value $=0,000$ lebih kecil dari $\alpha=0,05$ maka $\mathrm{H}_{0}: \mu_{1} \leq$ $\mu_{2}$ ditolak.

Sedangakn hasil observasi yang dilakukan di masing-masing kabupaten dari ketiga kabupaten menggambarkan bahwa hampir keseluruhan pengelolaan proses pelaksanaan pembelajaran di kelas SD Eks RSBI tidak berdasarkan tujuan SD Eks RSBI yaitu sebagai pusat pemberdayaan pengetahuan, pusat keterampilan sebagai mana telah dijelaskan pada bab kedua tentang tujuan SD Eks yaitu "untuk meningkatkan keprofesionalan satuan pendidikan SD sebagai pusat pembudayaan ilmu pengetahuan, keterampilan, pengalaman, sikap, dan nilai berdasarkan standar nasional dan internasional. Hal tersebut juga terlihat saat observasi berlangsung tentang kurang profesionalnya guru dalam mengajar, sehingga ketika saat membuat kesepakatan masih ada guru di sekolah SD Eks RSBI yang belum siap untuk di amati. Akan tetapi ada satu guru SD 4 Wates yang mengajar di kelas IV mengajar dengan sangat baik, inovasi pembelajaran yang beragam, pengelolaan kelas yang baik, metode mengajar yang sangat inovatif, mengorganisasikan kelas sehingga siswa-siswa di kelas menjadi sangat aktif dan memiliki mental yang sangat baik. Inilah yang menjadi penyebab dari hasil pengamatan berbeda. Akan tetapi dari hasil keseluruhan tersebut tentu terdapat beberapa hal yang menjadi akibat dan harus dikaji lebih lanjut. Berikut merupakan paparan analisis perbedaan proses pembelajaran dan prestasi belajar antara SDSN dan SD Eks RSBI di DIY:

Berdasarkan Kajian Teori yaitu Proses Pembelajaran Ditinjau dari Pengamatan Pelaksananaan Proses Pembelajaran

Sebagaimana telah dijelaskan oleh Rusman (2012, p.106) Memantau/mengamati pelaksanaan pembelajaran adalah kegiatan pemantauan (monitoring) yang menyertakan proses pengumpulan, penganalisaan, pencatatan, pelaporan dan penggunaan informasi manajemen tentang pelaksanaan kegiatan pembelajaran. hal ini menunnjukkan bahwa betapa pentingnya seorang guru harus melakukan sistem pembelajaran yang komunikatif, integratif dan menyenangkan, karena dengan melakukan pelaksanaan proses pembelajaran dengan cara tersebut pasti akan lebih memberikan pengaruh yang sangat luar biasa bagi perkembangan siswa, baik perkembangan secara kognitif, afektif dan psikomotoriknya.

Apabila diperhatikan lebih lanjut bahwa pelaksanaan proses pembelajaran ini tentu akan mengantongi berbagai macam informasi, mengumpulkan informasi tentang kemajuan dan kemunduran mutu dari pendidikan itu sendiri sehingga apabila diukur secara kognitif dengan cara memberikan penilaian dalam artian memberikan tes kepada siswa otomatis akan memberikan deskripsi tentang pencapaian keberhasilan dari materi yang telah dipelajari siswa. Hal inilah yang akan menjadi ukuran turun dan meningkatnya prestasi siswa tersebut.

Prestasi Belajar Ditinjau dari Tujuan dan Sasaran Pengajaran

Pada kajian teori dalam bab II dijelaskan bahwa Ketercapaian prestasi belajar yang tinggi memerlukan tujuan dan sasaran pengajaran yang harus dispesifikasikan dan dipahami, bukan hanya sekedar mengajarkan ilmu pengetahuan tersebut tanpa memahami indikator dari prestasi belajar tersebut, sebagaimana Olivia (1992, p.382) menjelaskan:

The instructional goals and objective should be spesified for three domains of leaning-the cognitife, the affective and the psychomotoric, whenever applicable. Note these three illustrations of different types of learning: (a) knowledge of the system of election primaries, (b) enjoyment in reading, (c)skill in laying bricks.

Hal ini menunjukkan bahwa ketercapaian dari prestasi siswa jika hanya mengacu kepada ranah kognitifnya saja maka tidak akan bisa disebut sebagai prestasi belajar, karena akibat dari seseorang melakukan pembelajaran yaitu dapat membentuk keperibadian dan keterampilan dari siswa tersebut. Oleh sebab itu berdasarkan dari hasil pengamatan dan observasi baik di dalam kelas maupun dilingkungan sekolah dari masing-masing sekolah yang dijadikan sebagai tempat penelitian masing-masing sekolah memiliki karakter dan kelebihan ma- 
sing-masing dalam menunjukkan segala kreatifitas dan keterampilan sekolah mereka, sehingga secara tidak langsung juga akan membentuk karakter dari siswa tersebut.

Prestasi Belajar Ditinjau dari Profesionalisme Guru

Ketercapaian prestasi yang tinggi akan sangat berpengaruh pada profesionalisme guru, karena dalam karakteristik anak pada masamasa pertengahan dan akhir dari masa anakanaknya, apapun yang terjadi dan yang diberikan didalam kelas itu sendiri akan mencontohi semuanya, oleh sebab itu guru harus selalu tampil profesional, mampu mengolah kelas dengan sebaik mungkin dan memiliki keterampilan dalam mendidik anak.

Hasil penelitian yang telah didapatkan berdasarkan hasil analisis data dan pengamatan di atas tidak akan bisa terlepas dari standar proses pendidikan SD Eks RSBI dan SDSN. Seperti yang telah diketahui bahwa standar proses pendidikan adalah standar nasional pendidikan yang berkaitan dengan pelaksanaan pembelajaran pada satu satuan pendidikan untuk mencapai standar komptensi lulusan. Dalam proses pembelajaran diselenggarakan secara interaktif, inspiratif, memotivasi, menyenangkan, menantang, mendorong peserta didik untuk berpartisipasi aktif, serta memberikan ruang yang cukup bagi prakarsa, kreativitas, dan kemandirian peserta didik sesuai dengan bakat, minat, dan perkembangan fisik serta psikologinya. Dalam proses pembelajaran pendidik memberikan keteladanan.

Pelaksanaan proses pembelajaran di SD Eks-RSBI 1 Bantul, dan SD Eks RSBI 1 Wonosari dari hasil pengamatan bahwa pelaksanaan proses pembelajaran secara interaktif, inspiratif dan mendorong peserta didik untuk berpartisipasi aktif masih belum terlaksana secara maskimal dan pengelolaan proses pembelajarannya sama dengan guru di sekolah SDSN.

Mencapai standar kompetensi kelulusan merupakan tujuan dari standar proses pendidikan, kompetensi kelulusan yang terdapat di sekolah SD Eks RSBI dan SDSN dapat di lihat dari hasil kelulusan UN pada tahun-tahun sebelumnya.

Apabila mengacu pada syarat standar pendidik dan tenaga kependidikan dari sekolah SD Eks RSBI dan SDSN, tentunya sudah terlihat jelas tentang kriteria standar pendidik dan tenaga kependidikan dari SD Eks RSBI. Akan tetapi berdasarkan hasil survei dan pengamatan standar pendidik dan tenaga kependidikan di SD Eks RSBI belum memenuhi kriteria dari syarat tenaga kependidikan SD Eks

Berdasarkan Uji Univariat Pengujian Prestasi Belajar dan Proses Pembelajaran IPA Siswa SDSN dan SD eks RSBI

Berdasarkan hasil analisis multivariat atau uji statistik two group MANOVA yaitu nilai signifikansi lebih kecil dari 0,05 didapatkan adanya perbedaan mean antara kelompok SD eks RSBI dan SD eks RSBI pada prestasi dan proses pembelajaran IPA. Kemudian adanya pengujian tindak lanjut dari uji multivariat setelah terdapat perbedaan dari kedua kelompok tersebut yaitu uji univariat dengan menggunakan uji t one sample sampel yang menunjukkan bahwa $\mathrm{t}_{\text {hitung }}<\mathrm{t}_{\text {tabel }}$, dengan kata lain $\mathrm{H}_{0}$ tolak.

Berdasarkan hasil analisis data menggunakan uji $t$ one sample menunjukkan bahwa $\mathrm{t}_{\text {hitung }}<\mathrm{t}_{\text {tabel. }}$ hasil tersebut memberikan ketegasan bahwa terdapat perbedaan proses pembelajaran dan prestasi belajar IPA siswa SD Eks RSBI dan SDSN di DIY.

Berdasarkan Uji Univariat Data Prestasi dan Proses Pembelajaran Bahasa Indonesia Siswa SDSN dan SD eks RSBI.

Berdasarkan hasil analisis multivariat atau uji statistik two group MANOVA yaitu nilai signifikansi lebih kecil dari 0,05 didapatkan adanya perbedaan mean antara kelompok SD eks RSBI dan SD eks RSBI pada prestasi dan proses pembelajaran bahasa indonesia. Kemudian adanya pengujian tindak lanjut dari uji multivariat setelah terdapat perbedaan dari kedua kelompok tersebut yaitu uji univariat dengan menggunakan uji $t$ one sample yang menunjukkan bahwa $t_{\text {hitung }}<t_{\text {tabel }}$, dengan kata lain $\mathrm{H}_{0}$ ditolak.

Berdasarkan hasil analisis data menggunakan uji $t$ one sample menunjukkan bahwa $\mathrm{t}_{\text {hitung }}<\mathrm{t}_{\text {tabel. }}$ hasil tersebut memberikan ketegasan bahwa terdapat perbedaan proses pembelajaran dan prestasi belajar Bahasa Indonesia siswa SD Eks RSBI dan SDSN di DIY.

\section{Berdasarkan Hasil Rata-Rata Angket Guru Proses Pembelajaran Kelompok Siswa SDSN dan SD eks-RSBI}

Hasil analisisis rata-rata (mean) dari kelompok guru SDSN dan SD eks RSBI menunjukkkan tidak ada perbedaan antara kedua kelompok tersebut, meskipun hasil guru SD eks RSBI lebih tinggi dan tidak jauh berbeda lebih 
tinggi dibandingkan dengan guru SDSN. Akan tetapi terlihat jelas mengapa rata-rata hasil angket guru di SD Eks RSBI dan SDSN tidak jauh berbeda, disebabkan karena pertama, hasil dari data tes prestasi belajar dan proses pembelajaran matematika siswa yang tidak berbeda dari hasil uji Multivariatnya, namun dari hasil rata-rata berdasarkan nilai meannya digambarkan hasil nilai tess pretasi belajar SD Eks RSBI lebih tinggi sedikit dibandingkan dengan SDSN, kedua hasil uji Multivariat pretasi belajar dan proses pembelajaran IPA siswa SDSN dan SD Eks RSBI yang menunjukkan terdapat perbedaan dari kedua kelompok tersebut, dimana berdasarkan hasil rata-rata (mean) prestasi belajar dan proses pembelajaran IPA siswa SDSN lebih tinggi dibandigkan dengan SD Eks RSBI, ketiga berdasarkan hasil uji Multivariat prestasi belajar dan proses pembelajaran Bahasa Indonesia siswa SD Eks RSBI dan SDSN yang menunjukkan terdapat perbedaan di antara kedua kelompok tersebut, terdapat perbedaan dari kedua kelompok tersebut terlihat juga dari hasil rata-rata (mean) yang menunjukkan bahwa prestasi belajar dan proses pembelajaran Bahasa Indonesia SD Eks RSBI lebih tinggi dibandingkan dengan SDSN, dan yang keempat berdasarkan hasil pengamatan, apabila mengacu secara keseluruhan kenapa dalam hasil angket guru memiliki tidak jauh perbedaan di antara kedua kelompok guru tersebut, jelas hal ini terlihat berdasarkan hasil pengamatan di lapangan, bahwa dari observasi keseluruhan sekolah kedua kelompok tersebut, rata-rata pelaksanaan proses pembelajaran di kedua kelompok tersebut sama dan tidak jauh berbeda.

\section{Simpulan dan Saran}

\section{Simpulan}

Berdasarkan hasil analisis pada penelitian ini dapat disimpulkan bahwa: (1) tidak terdapat perbedaan proses pembelajaran Matematika secara signifikan antara siswa SDSN dan SD Eks RSBI di DIY, (2) tidak terdapat perbedaan prestasi belajar Matematika secara signifikan antara siswa SDSN dan SD Eks RSBI di DIY atau dengan kata lain hipotesis awal ditolak, (3) terdapat perbedaan proses pembelajaran IPA secara signifikan antara siswa SDSN dan SD Eks RSBI di DIY atau dengan kata lain hipotesis awal diterima, (4) terdapat perbedaan prestasi belajar IPA secara signifikan antara siswa SDSN dan SD Eks RSBI di DIY atau dengan kata lain hipotesis awal diterima, (5) terdapat perbedaan proses pembelajaran Bahasa Indonesia antara siswa SDSN dan SD Eks RSBI di DIY atau dengan kata lain hipotesis awal diterima, (6) terdapat perbedaan prestasi belajar Bahasa Indonesia antara siswa SDSN dan SD Eks RSBI di DIY atau dengan kata lain hipotesis awal di terima.

Saran

Saran dalam penelitian ini adalah sebagai berikut: (1) bagi guru baik di SDSN maupun SD eks RSBI dapat berupaya baik secara pribadi dan bersama-sama/kolektif melatih, membiasakan dan meningkatkan tanggung jawabnya sebagai seorang pendidik, memberikan yang terbaik kepada peserta didik kita agar mereka benar-benar dapat memperoleh apa yang sebenarnya anak didik kita butuhkan dan implementasikan dalam kehidupan sehari-hari, (2) bagi kepala sekolah, hendaknya selalu melakukan pengamatan dan pengevaluasian dalam pelaksanaan proses pembelajaran agar secara siklus selalu ada hubungan yang signifikan baik antara siswa dengan guru, guru dengan kepala sekolah dan semua yang bertanggung jawab dalam terlaksananya sistem pendidikan tersebut, (3) bagi masyarakat dan stake holder terkait pendidikan di SDSN dan SD Eks RSBI supaya lebih berpartisipasi memberikan sumbangan pemikiran dan materilnya dalam usaha memajukan pendidikan, khususnya meningkatkan prestasi siswa dengan baik agar mereka kelak mampu mengemban benar-benar arti dari nilai pendidikan itu sendiri.

\section{Daftar Pustaka}

Azwar, Syaifuddin. (2012). Reliabilitas dan validitas. Edisi Keempat. Yogyakarta: Pustaka Pelajar.

Brown, G.F. (1981). Measuring classroom achievement. Lowa State University: Holt, Rinehart and Winston.

Bundu, P. (2006). Penilaian keterampilan proses dan sikap ilmiah dalam pembelajaran sains-SD. Depdiknas Direktorat Jendral Pendidikan Tinggi.

Harrow, A.J. (1971). A Taxonomy of the psychomotor domain. A Guide for Develobing Behavioral Objectives. New York: David McKay, INC.

Hergenhahn, B.R., \& Olson, M.H. (2010). Theories of learning. (diterjemahkan 
oleh Tri Wibowo B.S). Edisi Ketujuh. Jakarta: Kencana.

Jhonson, D.W. \& Jhonson, R.T. (2002). Meaning full assessment: a manageable and cooperative process. Boston: Allyn Bacon.

Kemendiknas. (2006). Peraturan Menteri Pendidikan Nasional Nomor 22, Tahun 2006, tentang Standar Isi untuk Satuan Pendidikan Dasar dan Menengah.

Kratwohl. D.R , Bloom, S.B, \& Masia, B.B. (1973). Taxonomy of educational objectives. The Classificatians of Educational Goals. Handbook II: Affective Domain. London: Longman Group LTD.

Mardapi, Djemari. (2012). Pengukuran, penilaian dan evaluasi pendidikan. Yogyakarta: Nuha Litera.

McMillan, J.H., \& Schumacher, S. (2010) Reseach in education. Seventh Edition.New Jersey: Publisher prior.

Oliva, F.P. (1992). Developing the curriculum. Author Supervision for Today's Schools. Third Edition. New York: Harpers Collisn Publishers.

Prasetyo, Zuhdan K. dkk. (2004). Kapita selekta pembelajaran fisika. Edisi
Kedua. Pusat Penerbitan Universitas Terbuka.

Republik Indonesia. (2003). Undang-Undang RI Nomor 20, Tahun 2003, tentang Sistem Pendidikan Nasional.

Reynolds, C.R., Livingston, R.B., \& Willson, V. (2009). Measurement and assesment in education. New Jersey : Pearson Education.

Rusman. (2012). Model-model pembelajaran, megembangkan profesionalisme guru. Edisi Kedua. Jakarta: PT Raja Grafindo Persada.

Sanjaya, W. (2008). Strategi pembelajaran berorientasi standar proses. Jakarta: Kencana.

Santrock, W.J. (2010). Psikologi pendidikan (terjemahan). Edisi Kedua. Jakarta: PT Fajar Interpratama Offset.

Stevens. J. (2002). Applied multivariate statistics for the social sciences. Fourth Edition. London: Lawrence Erlbaum Associates, Publisher.

Sukmadinata, S.N. (2012). Metode penelitian pendidikan. Bandung: PT Remaja Rosdakarya

Usman, H., \& Setiadi, P. (1995). Pengantar Statistika. Yogyakarta: Bumi Aksara 